\title{
VERIFYING THE PRODUCTION PROCESS OF DELICATESSEN RUSKS ACCORDING TO ISO 2200 NORM IN THE "MAMUT" COMPANY IN WROCEAW
}

\begin{abstract}
The present article evaluates and verifies the technological process of delicatessen rusks production in terms of its compatibility with the ISO 2200 norm. Risk analysis has been conducted which allowed to establish Critical Control Points (CCPs) and $\mathrm{CPs}$ - one CCP during the stage of raw material reception, and two CPs during heating and cooling. With the aid of the decision tree, critical borders for control measures for the CCP have been defined and located within the technological scheme reflecting the course of the technological process. Further requirements for CCP monitoring have been established, along with procedures for re-establishing the process and maintaining control, based on monitoring results. Finally, procedures for effective storing of HACCP documentation have been determined.
\end{abstract}

Key words: Mamut, delicatessen rusks, ISO 2200

\section{Introduction}

Delicatessen rusks are produced in accordance with the trade norm BN-78/8097-05 (solid confectionary products: delicatessen rusks). According to the EKD (Polish classification of products), delicatessen rusks belong to group 10 of food articles (10.72.11.0: crispbread; Dz.U. z 1997; nr 128.poz.829).

Product description (Delicatessen Rusks and their nutritional value)

1 Profesor nadzwyczajny UE., Wrocław University of Economics, e-mail: katarzyna.szoltysek@ue.wroc.pl 
Ingredients: wheat flour, sugar, yeast, palm oil, whey powder (from milk), salt, emulgator - lecithin (from soy), plant oils (palm, sunflower); may contain eggs.

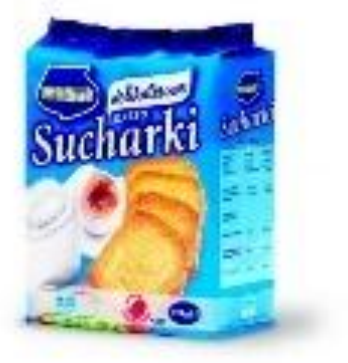

Fig. 1. Delicatessen rusks - packaging.

The rusks are baked from highest quality wheat flour. They are light, easy to digest and recommended during gastrointestinal disorders. They do not contain preservatives, and moisture below $10 \%$ allows them to stay fresh for as long as 8 months. Delicatessen rusks have been awarded with the "Poznaj Dobrą Żywność" Sign. Apart from delicatessen rusks (Image 1), Mamut produces also Extra Delicatessen Rusks. The rusks are available also without added sugars. This type of rusks is a dietary product from which saccharose has been eliminated and thus are particularly recommended for people who wish to lower their sugar intake. The recipe has been enriched with lecithin, which helps improve memory (1 slice contains only $40 \mathrm{kcal}$, no preservatives are added). 


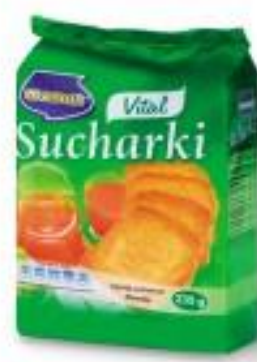

Fig. 2 .Delicatessen rusks VITAL.

The wheat flour used in the baking process contains a greater amount of dietary fibre. Adding plant oils, whey powder and lecithin guarantees their exceptional crunchiness and taste. The rusks are a very good source of fibre, which is essential for proper digestion.

Table 1. General Information on rusks with raisins

\begin{tabular}{|l|l|l|l|l|}
\hline Weight & Packaging & $\begin{array}{l}\text { Amount on } \\
\text { tray }\end{array}$ & Shelf life & EAN-13 \\
\hline $230 \mathrm{~g}$ & $\begin{array}{l}\text { Box with 15 } \\
\text { pieces }\end{array}$ & 48 & 8 months & 5900697016740 \\
\hline
\end{tabular}




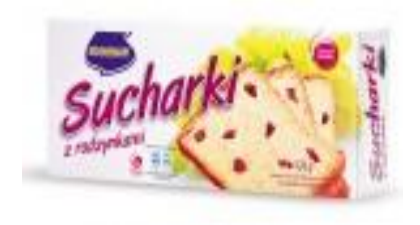

Fig.3. Rusks with raisins: packaging.

a great snack for active people,

light and easily digestible,

contain lecithin which enhances concentration during periods of high intellectual activity,

packed in three separate sachets, each containing 4 rusks.

\section{A general characteristic of the MAMUT Company}

The MAMUT Company is one of the largest producers of baking and confectionery articles in the Lower Silesian region, whose offer and range of products is the broadest and most diversified in Poland. The goods MAMUT manufactures are also acknowledged abroad, exactly due to the wide choice of products and their excellent taste. The company's stable position in the market and advanced distribution network make MAMUT a reliable partner to cooperate with. The origins of the company go back to the second half of the $19^{\text {th }}$ century, when the Wrockaw Consumer Cooperative was founded. The co-op laid the foundations for the development of the baking industry in the capital of Lower Silesia. Throughout the following 55 years, the enterprise grew and its production profile extended to include also confectionery articles. Since 1989 the 
company operates as an independent economic unit. In 2000, it took on the name of SZPC MAMUT; in 2007 the company commences its activity as MAMUT Ltd. The company is the beneficiary of an EU grant within the scope of the programme "Innovative Economy." European Union projects National Strategic Reference Framework DOTATIONS FOR INNOVATIONS: Title of project: "New line of high quality durable bakers' products" Beneficiary: MAMUT Ltd. Project Value: 8414 340, 00 PLN EU Subsidy: 2788 800, 00 PLNProject Duration: 2012 - 2016. (Materiały firmy Mamut). (1)

MAMUT offers a broad variety of products: Bakers' goods, Bread crumbs, Rusks, Croutons, Skorpora croutons, Sugar confectionary, Ladyfingers, Meringues, Peas puff pastries.

Several years ago, MAMUT offered only a couple of durable goods; today, the company is one of the largest producers of bakers' and sugar confectionery, boasting a rich range of articles. Production processes are all based on reliable, traditional recipes; the company uses only highquality raw materials and ingredients. Many of Mamut's products have been awarded important prizes. The quality of the products, their nutritional value, excellent taste, and new and aesthetic packaging mean that the company's articles are widely sought after by consumers.

The key to success is distribution. Thanks to swift transport and an advanced network of wholesale plants, MAMUT is generally considered to be a reliable partner and supplier. In order to keep up the high standards and continue to meet clients' and consumers' expectations, MAMUT experts constantly work on further developing and strengthening the distribution network. A new challenge has also emerged - Eastern and Central European markets, to which MAMUT is now exporting their goods. 


\section{Reasons for increased interest in food safety systems}

Several methods have been established with the aim to providing food safety. The solutions may easily be implemented as systems in various enterprises. Implementing a food safety system allows companies to categorize and order all actions concerned with providing quality products, in particular when it comes to the safety of produced goods, that is - change in conduct and procedures, and shifting responsibility to employers directly involved in production processes. Food safety systems also enable the companies to produce goods of a consistently high quality, through processes designed so as to avoid the production of goods failing to meet the requirements of, for instance, health quality of food. Systems used in food production are supposed to prevent problems before they could emerge, and to help take conscious improvement actions so as to safeguard against producing goods of a lower than desired quality. The basis for integrated systems of food health quality consists of Good Manufacturing Practice (GMP) and Good Hygienic Practice (GHP). Another vital system is HACCP (Hazard Analysis and Critical Control Point). Today, questions of food safety become more and more important for consumers. Providing food quality is much more complex than providing quality of non-food products, mostly because when evaluating food a range of its properties have to be considered, which together decide about the product's final quality, for instance food safety (the guarantee that food will not cause any harm to the consumer, on condition that it is prepared and consumer in accordance with its original purpose). Food safety refers also to food hazards at the moment of product consumption, and is not related to other aspects influencing a man's health, e.g. improper nutritional habits. Food health quality denotes features and criteria which are used to characterise food with regards to its nutritional value, organoleptic quality, and consumer health safety.

The management and staff of any restaurant, who according to the law are treated as food producers, take full responsibility for the health 
quality of the food they produce. They are obliged to guarantee the safety and health quality of articles which they sell, through implementing in everyday practice systems of quality management and control, in particular Good Hygienic Practice (GHP).

ISO 2200 - Requirements for all organisations belonging to the nutritional value chain (PN-EN ISO 22000-Systemy zarządzania bezpieczeństwem żywności).

Ever since Poland joined the European Union, it had to standardize nutrition legislation and adjust the food processing sector to the standards valid across the EU. In this context, the ISO 2200 Norm acquires special significance.

In 2005, the International Organization for Standardization (ISO) published a new norm for the food sector, which listed requirements essential for constant supply of safe products and services. The norm belongs to the 2200 series. In May 2006 the norm was officially embraced by the Polish Committee for Standardization, and functions in Poland as the Polish norm PN-EN ISO 2200: 2006. (PN -EN ISO $2200-$ System zarządzania bezpieczeństwem żywności)(2)

The most important element of food safety management is the awareness of the role each subject present on the market plays in food production, both in an indirect and direct way, i.e. through belonging to a specific place in the nutrition chain - from original production (farmers), up to consumers. The nutrition chain consists of a range of stages, processes, actions, and procedures for producing, processing, distributing, and storing food articles. Thus, food safety will only be guaranteed when all the links in the chain are joined by means of swift and communication, and when particular rules and regulations will be clearly stated and obeyed.

The ISO 2200 norm is addressed to: 1. Farm goods producers; 2. Fodder producers; 3. Primary products producers; 4. Food articles manufacturers; 5. Transportation operators (logistics and transport companies); 6. Storage companies; 7. Wholesale plants; 8 . Subcontractors of the above; 9. Retailers; 10. Food services providers (restaurants, bars, 
caterers); 11. Machine and appliances producers; 12. Packaging producers; 13. Cleaning agents and industrial chemicals producers; 14. Ingredients and additives producers; 15. Pesticide, fertilizer, medicine, and dietary supplements producers.

The norm joins key elements in the supply chain which guarantee food safety, including:

- Interactive communication.

- Standardized management system.

- Means for hazard analysis and hazard control through.

HACCP (Ustawa z dnia 25 sierpnia 2006 r. o bezpieczeństwie żywności i żywienia;(7) Rozporządzenie Parlamentu Europejskiego z dnia 28. Stycznia 2002 r. ustalające ogólne zasady i wymagania prawa żwnościowego, ustanawiające Europejski Urząd d/s Bezpieczeństwa Żywności oraz ustanawiające procedury w sprawie bezpieczństwa) (8)

Food safety management system was adjusted to the structure of the ISO 9001:2000 norm, with which it shares several features, for instance requirements regarding documentation supervision, the management's responsibility for supervising resources. Integrating the systems does not pose a challenge; thus, it allows for full control over hazards which might emerge at any of the stages of the food safety chain.

\section{Own research}

In order to verify the technological process of rusks a meticulous analysis was conducted of the stages of the production of rusks, referring them to most common food hazards (Table 1).

Table 2. Food hazards

\begin{tabular}{|l|l|l|}
\hline Biological & Chemical & Physical \\
\hline Nosogenic & Natural - from raw & Natural - bones, fishbones, \\
\hline
\end{tabular}




\begin{tabular}{|l|l|l|}
\hline microorganisms & materials & stones, sand \\
\hline $\begin{array}{l}\text { Saprophytic } \\
\text { microorganisms }\end{array}$ & $\begin{array}{l}\text { Agricultural- } \\
\text { breeding }\end{array}$ & $\begin{array}{l}\text { Plastics - plastic pieces from } \\
\text { packaging and/or machines }\end{array}$ \\
\hline Parasites & Functional additives & $\begin{array}{l}\text { Metal - filings or machine } \\
\text { pieces and parts }\end{array}$ \\
\hline Pests & $\begin{array}{l}\text { Hygenization } \\
\text { residues }\end{array}$ & Glass \\
\hline Prions & $\begin{array}{l}\text { Of microbiological } \\
\text { origin }\end{array}$ & Wood \\
\hline & & $\begin{array}{l}\text { Other foreign bodies - hairs, } \\
\text { buttons, accessories }\end{array}$ \\
\hline
\end{tabular}

In order to establish the frequency (probability A) and significance (B) of adverse or potentially adverse health hazards (P), the risk priority scale was applied, in which

$$
\mathbf{P}=\mathbf{A x B}
$$

Basing on this equation, risk priority and its verification was conducted, allowing for three possible values:

$\mathbf{P}<\mathbf{3}$ - to avoid the hazard it is enough to apply preventive actions and, if need be, control point (CP),

$\mathbf{P}=\mathbf{3}$ - person in charge of hazard analysis decides whether preventive actions is enough or whether it is necessary to determine the critical control point (CCP),

$\mathbf{P}>\mathbf{3}-$ it is necessary to establish adequate measures in the production cycle, in which the particular hazard will be under constant control thanks to the critical control point (CCP). 


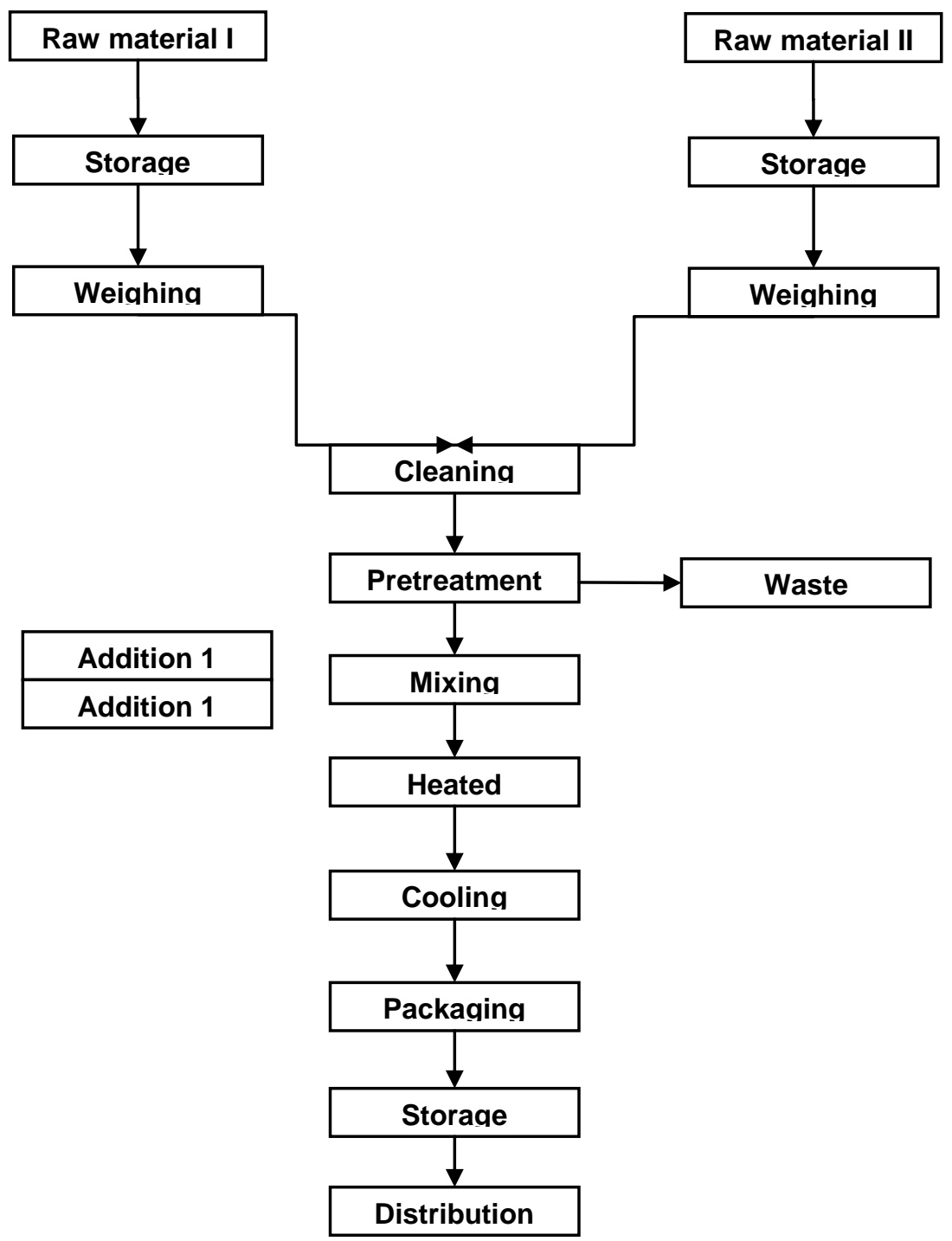

Fig. 4. Technological scheme for the production of delicatessen rusks 
The above-presented analysis led to determining: One CP and Two CCPs

\section{Conclusions}

As a result of the above-presented meticulous analysis, in the course of which two control points have been implemented into the technological process of the production of delicatessen rusks, it can be assumed that their production process conforms to the requirements of food safety standards.

According to the Codex Alimentarius and Food Hygiene Basis, the term "food safety" means that a particular food article will cause no harm or damage to a consumer's health, provided that the item has been prepared properly and is consumed in accordance with its intended purpose. In this light, safe food describes food articles free from health-threatening factors: biological (including microbiological), chemical, and physical.

\section{Bibligraphy}

1. CODEX ALIMENTARIUS International food standards (Codex

Alimentarius)

2. Europejska Klasyfikacja Działalności (EKD

3. Rozporządzenie Rady Ministrów z 7 października 1997 r. w sprawie Polskiej Klasyfikacji Działalności (PKD) (Dz. U. z 1997 r. Nr 128, poz. 829)

4. Materiały firmy MAMUT: Opis produktu

5. Rozporządzeniu Parlamentu Europejskiego i Rady Nr 178/2002 z dnia 28 stycznia 2002 r. ustalającego ogólne zasady i wymagania prawa żywnościowego, ustanawiające Europejski Urząd ds. Bezpieczeństwa Żywności oraz ustanawiające procedury w sprawie bezpieczeństwa żywnościowego

6. USTAWA z dnia 25 sierpnia 2006.z dnia 25 sierpnia 2006 o bezpieczeństwie żywności i żywienia

7. PN-EN ISO 22000 - System zarządzania bezpieczeństwem żywności

8. http://www.who.int/foodsafety/areas_work/food-standard/en/ 